\title{
Formation of Actin Filament Networks in Cultured Rat Hepatocytes Treated with DMSO and Glucagon
}

\author{
Takashi Kojima ${ }^{1,3}$, Chihiro Mochizuki ${ }^{1}$, Hirotoshi Tobioka², Masato Saitoh ${ }^{2}$, Shuji Takahashi², \\ Toshihiro Mitaka ${ }^{1}$, and Yohichi Mochizuki ${ }^{1}$ \\ ${ }^{1}$ Department of Pathology, Cancer Research Institute, Sapporo Medical University School of Medicine, Sap- \\ poro 060, Japan and ${ }^{2}$ Department of Pathology, Sapporo Medical University School of Medicine, Sapporo 060, \\ Japan
}

Key words: Actin filament networks/primary rat hepatocytes/DMSO/glucagon

\begin{abstract}
$A B S T R A C T$. Actin filament organization may play an important role in the maintenance of differentiated functions in epithelial cells. We previously reported our success in inducing and maintaining gap junctions, which are two kinds of differentiated function, in primary rat hepatocytes cultured with $2 \%$ DMSO and $10^{-7} \mathrm{M}^{-1}$ glucagon. In the present study, we demonstrated the formation of actin filament networks in the hepatocytes cultured with $2 \%$ DMSO and $10^{-7} \mathrm{M}$ glucagon. Actin filaments in hepatocytes cultured in medium with only $2 \%$ DMSO added from $96 \mathrm{~h}$ after plating were concentrated under the plasma membrane and were observed to be circumferential. In hepatocytes cultured in the medium with both $2 \%$ DMSO and $10^{-7} \mathrm{M}$ glucagon added from $96 \mathrm{~h}$, not only the circumferential actin filaments but also the formation of actin filament networks were observed and the networks developed well with time in culture. The networks were observed as a dome-like structure under the cell face and terminated at the circumferential actin filaments. They were composed of electrondense star-like vertices connected by microfilament bundles of varying length and were also very sensitive to the actin disruptor cytochalasin B. However, during the network formation, there were no significant increases in the amounts of actin protein and mRNA. The actin filament networks of the hepatocytes in this culture system might be closely related to the maintenance of differentiated functions.
\end{abstract}

Actin filaments are constitutive cytoskeleton components involved in determining cell shape and contrast. They may play an important role in the maintenance of differentiated function in epithelial cells. In addition, the polymerization state of actin filaments, which can change under the influence of growth factors and other hormones by shifting of the actin monomer/polymer actin equilibrium, has repeatedly been suggested to be important for cellular functions (1).

In the liver, actin filaments of hepatocytes are involved in three distinct zones; the plasma membrane-associated zone, circumferential pericanalicular zone and

\footnotetext{
3) To whom reprint requests/correspondence should be addressed at the Department of Pathology, Cancer Research Institute, Sapporo Medical University School of Medicine, S.1, W.17, Chuo-ku, Sapporo 060, Japan.

Tel: 81-11-611-2111 ext. 2392, Fax: 81-11-615-3099

Abbreviations: heat shock protein, HSP; connexin, Cx; dimethylsulfoxide, DMSO; Hanks balanced salt solution, HBSS; bovine serum albumin, BSA; epidermal growth factor, EGF; phosphate-buffered saline, PBS; room temperature, RT; fluorescein isothiocyanate, FITC; rhodamine-phalloidin, RP; horseradish peroxidase, HRP; 3,3'-diaminobenzidine, DAB.
}

microvillous cores $(2,3)$. In cultured hepatocytes, actin filaments are observed to be stress-fiber-like at the cell periphery in areas with extending lamellipodia at an early stage of polarization (4). They are organized into circumferential actin filament bundles by the interaction between the cells and their surrounding extracellular matrix $(\mathrm{ECM})(5,6,7)$.

We previously showed that in primary cultures of adult rat hepatocytes, a liver gap junction protein, connexin 32 (Cx32) is reexpressed in modified L-15 medium supplemented with epidermal growth factor (EGF) and $2 \%$ dimethylsulfoxide (DMSO) (8) and that the other liver gap junction protein, connexin $26(\mathrm{Cx} 26)$ could be also induced by the addition of $10^{-7} \mathrm{M}$ glucagon together with $2 \%$ DMSO (9). Recently, in hepatocytes cultured with medium supplemented with $2 \%$ DMSO and $10^{-7} \mathrm{M}$ glucagon, we found dramatic network formation by actin filaments. In the present study, we show the changes of actin filament organization in hepatocytes during culture. 


\section{MATERIALS AND METHODS}

Isolation and culture of rat hepatocytes. Male SpragueDawley rats (Shizuoka Laboratory Animal Center, Hamamatsu, Japan) weighing about $300-400 \mathrm{~g}$ were used to isolate hepatocytes by the two-step liver perfusion method of Seglen (10) with some modification. Briefly, the liver was perfused in situ through the portal vein with $150 \mathrm{ml}$ of $\mathrm{Ca}^{2+}, \mathrm{Mg}^{2+}$-free Hanks balanced salt solution (HBSS) supplemented with 0.5 mM EGTA (Sigma Chemical Co., St. Louis, MO), $0.5 \mathrm{mg} / \mathrm{L}$ insulin (Sigma) and antibiotics. After the initial brief perfusion, the liver was perfused with $200 \mathrm{ml}$ HBSS containing 40 $\mathrm{mg}$ of collagenase (Yakulto Co., Tokyo, Japan) for $15 \mathrm{~min}$. The isolated cells were purified by Percoll iso-density centrifugation (11). Viability of the cells by the trypan blue exclusion test was more than $90 \%$ in these experiments. The cells were suspended in L-15 medium with $0.2 \%$ bovine serum albumin (BSA; Seikagaku Kogyo Co., Tokyo, Japan), 20 mM HEPES (Dojindo, Kumamoto, Japan), $0.5 \mathrm{mg} / \mathrm{L}$ insulin (Sigma), $10^{-7} \mathrm{M}$ dexamethasone (Sigma), $1 \mathrm{~g} / \mathrm{L}$ galactose (Sigma), 30 $\mathrm{mg} / \mathrm{L}$ proline (Sigma), and antibiotics. The hepatocytes were plated on $35 \mathrm{~mm}$ or $60 \mathrm{~mm}$ culture dishes (Corning Glass Works, Corning, NY), which were coated with rat tail collagen (500 $\mu$ g of dried tendon $/ \mathrm{ml}$ of $0.1 \%$ acetic acid) (12), and placed on a $100 \%$ air incubator at $37^{\circ} \mathrm{C}$. Two to three hr after plating, the medium was changed to L-15 medium supplemented with $0.2 \%$ BSA, $20 \mathrm{mM}$ HEPES, $0.5 \mathrm{mg} / \mathrm{L}$ insulin, $10^{-7} \mathrm{M}$ dexamethasone, $1 \mathrm{~g} / \mathrm{L}$ galactose, $30 \mathrm{mg} / \mathrm{L}$ proline, 20 $\mathrm{mM} \mathrm{NaHCO} 3,5 \mathrm{mg} / \mathrm{L}$ transferrin (Wako Pure Chemical Inc., Osaka, Japan), $0.2 \mathrm{mg} / \mathrm{L} \quad \mathrm{CuSO}_{4} \cdot 5 \mathrm{H}_{2} \mathrm{O}, 0.5 \mathrm{mg} / \mathrm{L}$ $\mathrm{FeSO}_{4} \cdot 4 \mathrm{H}_{2} \mathrm{O}, 0.75 \mathrm{mg} / \mathrm{L} \mathrm{ZnSO} \cdot \mathrm{ZH}_{2} \mathrm{O}, 0.05 \mathrm{mg} / \mathrm{L} \mathrm{MnSO}_{4}$, $5 \mu \mathrm{g} / \mathrm{L} \mathrm{Na}_{2} \mathrm{SeO}_{3}, 10 \mathrm{ng} / \mathrm{ml}$ EGF (Collaborative Res. Inc., Lexington, MA), and antibiotics. The cells were then placed in a humidified, $5 \% \mathrm{CO}_{2}: 95 \%$ air incubator at $37^{\circ} \mathrm{C}$. The medium was replaced with fresh medium every other day, and $2 \%$ DMSO (Aldrich Chemical Co. Inc., Milwaukee, WI) were added after $96 \mathrm{~h}$ of culture (8). Some dishes were cultured in $2 \%$ DMSO medium supplemented with $10^{-7} \mathrm{M}$ glucagon (Glucagon Novo, Yamanouchi, Tokyo, Japan) from $96 \mathrm{~h}$ (9).

Furthermore, after some of the cells were cultured in 2\% DMSO medium with $10^{-7} \mathrm{M}$ glucagon until day 10 , they were treated with 20 or $50 \mathrm{mg} / \mathrm{ml}$ cytochalasin B (Sigma) for $24 \mathrm{~h}$.

Immunofluorescence microscopy. The cells grown on coated glass cover slips (BIOCOAT, Becton Dickinson Labware) were fixed with acetone for $30 \mathrm{~min}$ at $-20^{\circ} \mathrm{C}$. After rinsing with phosphate-buffered saline (PBS), the coverslips were incubated with rhodamine-phalloidin (RP, Sigma) at room temperature (RT) for $1 \mathrm{~h}$. The samples were examined with a Nikon Fx epifluorescence photomicroscope (Nikon, Tokyo, Japan).

Confocal laser microscopy. Some of the cultured cells processed for RP staining were examined with an MRC 500 confocal laser microscope (Bio-Rad, Richmond, CA) and by three-dimensional reconstruction of images of serial optical sections. Images were reconstructed on a Nimbus $\mathrm{AX} / 2$ per- sonal computer equipped with the "SOM" program (Research Machines Ltd., Oxford, UK). The number of optical sections was 9 and the interval was $1 \mu \mathrm{m}$.

Electron microscopy. The cells were fixed in $2.5 \%$ glutaraldehyde $/ 0.1 \mathrm{M}$ cacodylate buffer ( $\mathrm{pH} 7.3$ ) overnight at $4{ }^{\circ} \mathrm{C}$, postfixed in $2 \%$ osmium tetroxide in the buffer, dehydrated by graded ethanol, embedded in situ in Epon 812, and ultrathin sections were cut in a Sorvall Ultramicrotome MT-5000. The sections were stained with uranyl acetate followed by lead citrate and examined at $60 \mathrm{KV}$ with a JEM transmission electron microscope (JEOL, Tokyo, Japan).

Northern blot analysis and densitometry. Total RNA was extracted from the cells using the single-step thiocyanate-phenol-chloroform extraction method (13) as modified by Xie and Rothblum (14). For the electrophoresis, $10 \mu \mathrm{g}$ of total RNAs was loaded on $1 \%$ agarose gel containing $0.5 \mathrm{mg} / \mathrm{L}$ ethidium bromide. Gels were capillary-blotted in $20 \times$ standard saline citrate (SSC) onto a nylon membrane (Hybond-N; Amersham Corp., Buckinghamshire, UK) and fixed by ultraviolet light. For detection of $\beta$-actin mRNA, digoxigenin (DIG)-labeled RNA probes were prepared from $\beta$-actin cDNAs (Oncogene Science, Inc., NY), using an RNA labeling kit (Boehringer Mannheim, Mannheim, Germany). Hybridization, washing and chemiluminescent detection were carried out following the DIG luminescent protocol (15). Scanning-densitometry was performed using a Macintosh LC-520 computer (Apple Computer, Cupertino, CA) and an EPSON GT-5000 scanner (Seiko Epson, Suwa, Japan). The signals were quantified by the NIH Image 1.52 Densimetric Analysis Program (Wayne Rasband, NIH, Bethesda, MD) $(8,9,16)$.

Western blot analysis. The dishes were washed with PBS twice and $1 \mathrm{ml}$ of the buffer $(1 \mathrm{mM} \mathrm{NaHCO}$ and $2 \mathrm{mg} / \mathrm{L}$ leupeptin [Sigma]) were added to $60-\mathrm{mm}$ dishes. The cells were scraped and collected in the eppendorf tubes and then sonicated for $30 \mathrm{sec}$. The sonicates were centrifuged at $4500 \mathrm{~g}$ for $10 \mathrm{~min}$. The final pellets were resuspended in Laemmli sample buffer (17) without dithiothreitol (DTT). The protein concentration of the samples was determined using a protein assay kit (Bio-Rad, Richmond, CA). Twenty $\mu \mathrm{g}$ of protein of each sample per lane was treated with DTT (final concentration of $100 \mathrm{mM}$ ) and then loaded on $12.5 \%$ SDS-polyacrylamide gel (Daiichi Pure Chemicals Co., Tokyo, Japan). After electrophoretic transfer to a nitrocellulose membrane (Bio-Rad) using semi-dry blotting for $6 \mathrm{~h}\left(0.65 \mathrm{~mA} / \mathrm{cm}^{2}\right)$, the membrane was stained with Ponceau S (Sigma) and photographed. Thereafter, the membrane was saturated overnight at $4{ }^{\circ} \mathrm{C}$ with a blocking buffer ( $25 \mathrm{mM}$ Tris, pH 8.0, $125 \mathrm{mM} \mathrm{NaCl}, 0.1 \%$ Tween 20,4\% skim milk) and was incubated with a rabbit polyclonal anti-actin antibody (ICN Immuno Biologicals, IL) at $\mathrm{RT}$ for $2 \mathrm{~h}$. The membranes were incubated with horseradish peroxidase (HRP)-conjugated anti-rabbit IgG (DAKO) at RT for $1 \mathrm{~h}$ and 3,3'-diaminobenzidine (DAB) was used as a substrate. 


\section{RESULTS}

Actin filament organization. RP staining was carried out to examine actin filament organization of the cultured hepatocytes at $8 \mathrm{~h}, 24 \mathrm{~h}, 48 \mathrm{~h}, 96 \mathrm{~h}$, day 6 , day 10 and day 14 after plating (Fig. 1). The hepatocytes were cultured in $2 \%$ DMSO medium supplemented with or without $10^{-7} \mathrm{M}$ glucagon from $96 \mathrm{~h}$. In the hepato-
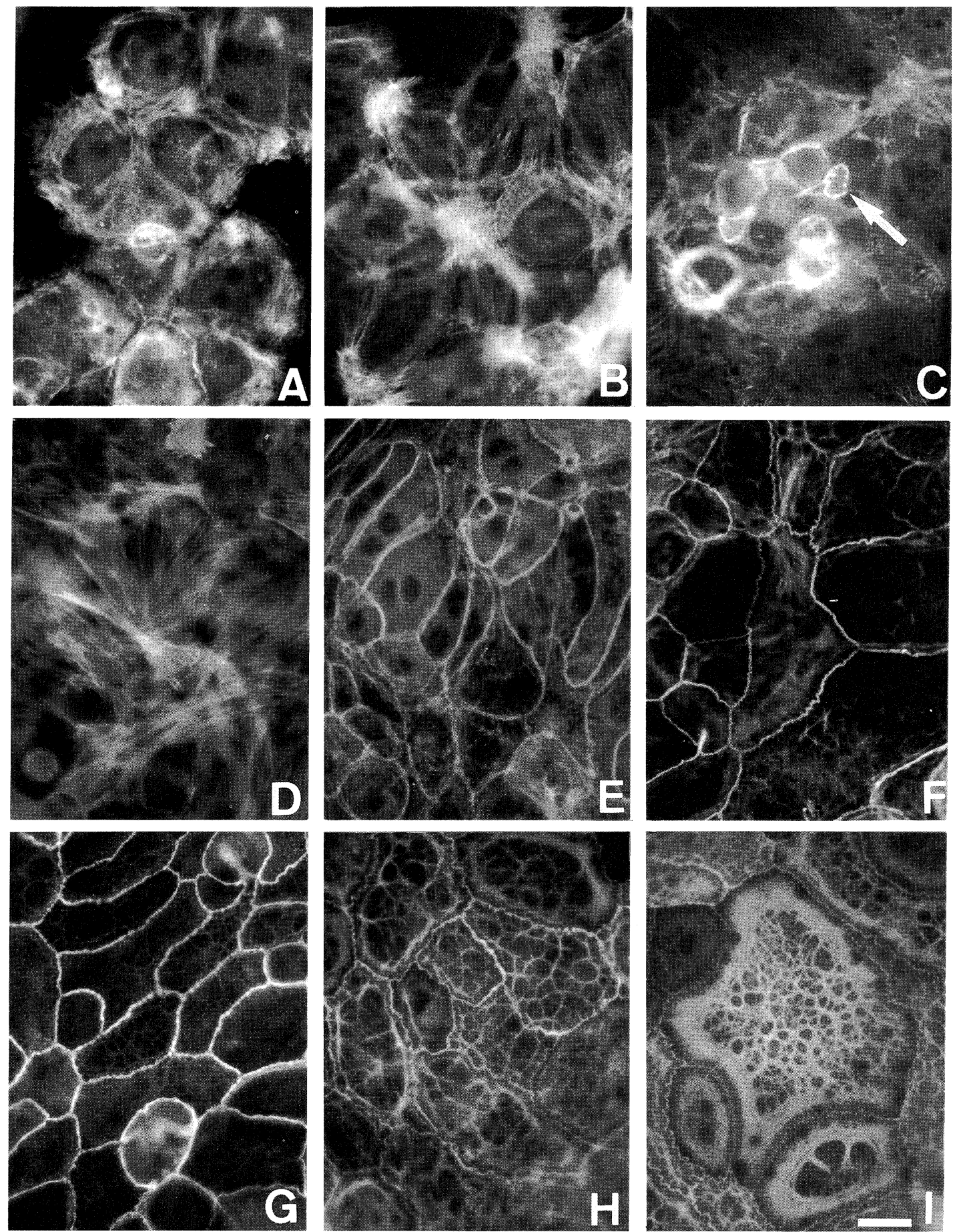

Fig. 1. Fluorescent cytochemistry of rhodamine-phalloidin in primary cultured rat hepatocytes. (A) $8 \mathrm{~h}$ after plating, (B) $24 \mathrm{~h}$, (C) $48 \mathrm{~h}$, a bile canaliculus-like structure was observed (arrow). (D) $96 \mathrm{~h}$. The medium was changed to medium with $2 \%$ DMSO (E, F) or with $2 \%$ DMSO and $10^{-7} \mathrm{M}$ glucagon (G, H, I) from $96 \mathrm{~h}$. (E, G) Day 6, (F, H) Day 10, (I) Day 14. All figures are the same magnification. Bar, $10 \mu \mathrm{m}$. 
cytes cultured at $8 \mathrm{~h}$, actin filaments were observed as stress-fiber-like bundles which extended out to the cell periphery (Fig. 1A). In the hepatocytes cultured from $24 \mathrm{~h}$ to $96 \mathrm{~h}$, the stress-fiber-like bundles were observed not only at the cell periphery but also in the cytoplasm, although the rings were observed around bile canaliculilike structures at $48 \mathrm{~h}$ (Fig. 1B, C and D). In the hepatocytes cultured in $2 \%$ DMSO medium without $10^{-7} \mathrm{M}$ glucagon from $96 \mathrm{~h}$, actin filaments were concentrated under the plasma membrane at the cell boundaries and they were observed as circumferential actin filament bundles (Fig. 1E and F). The circumferential actin filament bundles were well maintained during the culture. In the hepatocytes cultured in 2\% DMSO medium with $10^{-7} \mathrm{M}$ glucagon from $96 \mathrm{~h}$, when actin filaments began to concentrate under the plasma membrane at the cell boundaries, networks of actin filaments appeared on some of the cells (Fig. 1G). The filament networks developed well with time in culture and the networks were observed on most cells (Fig. 1H and I). Some of the circumferential actin filament bundles at day 14 were also markedly thicker than at day 6 (Fig. 1I).

Confocal laser microscopy. To better resolve the localization of actin filaments during the culture, we used confocal laser microscopy to examine $1 \mu \mathrm{m}$ optical sections of the cultured cells stained with RP (Fig. 2). At $96 \mathrm{~h}$, the cultured hepatocytes were flattened and the cells were observed until 5 sections from the basal region. Stress-fiber-like bundles at the cell periphery were observed in all sections and long parallel bundles were observed in the 1st and 2nd sections from the basal region (Fig. 2A and B). In the hepatocytes cultured in 2\% DMSO medium with or without $10^{-7} \mathrm{M}$ glucagon from $96 \mathrm{~h}$, the cells were thick and were observed until $9 \mathrm{sec}-$ tions from the basal region at day 10. In the hepatocytes cultured in $2 \%$ DMSO medium without $10^{-7} \mathrm{M}$ glucagon, circumferential actin filament bundles were observed in all sections and short stress-fiber-like bundles were also observed in the 1st section from the basal region (Fig. $2 \mathrm{C}$ and $\mathrm{D}$ ). In the hepatocytes cultured in 2\% DMSO medium with $10^{-7} \mathrm{M}$ glucagon, the networks of actin filaments were observed from the 6th section to the 9th section (Fig. 2E and F). The circumferential actin filament bundles and the short stress-fiber-like bundles were observed (Fig. 2E). The actin filaments that formed the networks terminated at the circumferential actin filaments under the plasma membrane at the cell boundaries.

To examine the effect of an actin disruptor on actin filaments after the cells were cultured in 2\% DMSO medium with $10^{-7} \mathrm{M}$ glucagon until day 10 , the cells were treated with 20 or $50 \mathrm{mg} / \mathrm{ml}$ cytochalasin B for $24 \mathrm{~h}$. The cells treated with $20 \mathrm{mg} / \mathrm{ml}$ cytochalasin B became flattened and were observed until the 5th section from the basal region. The networks of actin filaments from the 6th to the 9th section disappeared, while the circumferential actin filament bundles were maintained (Fig. $3 \mathrm{~A})$. In the cells treated with $50 \mathrm{mg} / \mathrm{ml}$ cytochalasin B, both the circumferential actin filament bundles and the networks of actin filaments disappeared (Fig. 3B). However, when the cells were cultured without cytochalasin $\mathrm{B}$ for $24 \mathrm{~h}$ after the treatment with $20 \mathrm{mg} / \mathrm{ml}$ cytochala$\sin \mathrm{B}$ for $24 \mathrm{~h}$, the networks recovered completely (data not shown).

Electron microscopy. In the cells cultured in 2\% DMSO medium with $10^{-7} \mathrm{M}$ glucagon at day 10 , polygonal networks of microfilaments were observed (Fig. 4). They were composed of electron-dense star-like vertices connected by microfilament bundles of varying length (Fig. 4A and B). In the area of the networks, no organelles were detected (Fig. 4B). The microfilaments terminated at the plasma membrane (Fig. 4C).

Expression of $\beta$-actin $m R N A$ and actin proteins. Figure 5A shows the changes in the amount of $\beta$-actin mRNA in the cultured hepatocytes. Without DMSO treatment (until $96 \mathrm{~h}$ after plating), the amount of $\beta$-actin mRNA increased twofold from $24 \mathrm{~h}$ compared to isolated cells and the expression was maintained at a high level until $96 \mathrm{~h}$. In the cells cultured in 2\% DMSO medium with or without $10^{-7} \mathrm{M}$ glucagon from $96 \mathrm{~h}$ (from day 6 to day 14), the expression of $\beta$-actin mRNA was well maintained and no difference of the expression between cultures with and without $10^{-7} \mathrm{M}$ glucagon was observed. Figure 5B shows the changes in the amount of actin proteins in the cultured hepatocytes. No difference of expression between cultures with and without $10^{-7} \mathrm{M}$ glucagon was observed.

\section{DISCUSSION}

In the present study, we demonstrated the formation of actin filament networks in primary rat hepatocytes cultured with DMSO and glucagon. The networks of actin filaments in the cells were sensitive to an actin disruptor, cytochalasin B. There were no significant increases in the amounts of actin protein and mRNA during the network formation.

Actin filament organization in hepatocytes is well reported. In cultured rat hepatocytes, actin filaments are observed as stress-fiber-like bundles at the cell periphery at an early stage of polarization and they are organized into circumferential actin filament bundles by the interaction between the cells and their surrounding extracellular matrix $(\mathrm{ECM})(5,6,7)$. Recently, Ezzell et al. (4) reported that in cultured rat hepatocytes sandwiched between two layers of collagen gel, actin filaments were concentrated under the plasma membrane in regions of cell-cell contact. On the other hand, for the purpose of maintaining differentiated hepatic functions, $2 \%$ DMSO is used in primary cultures of rat hep- 

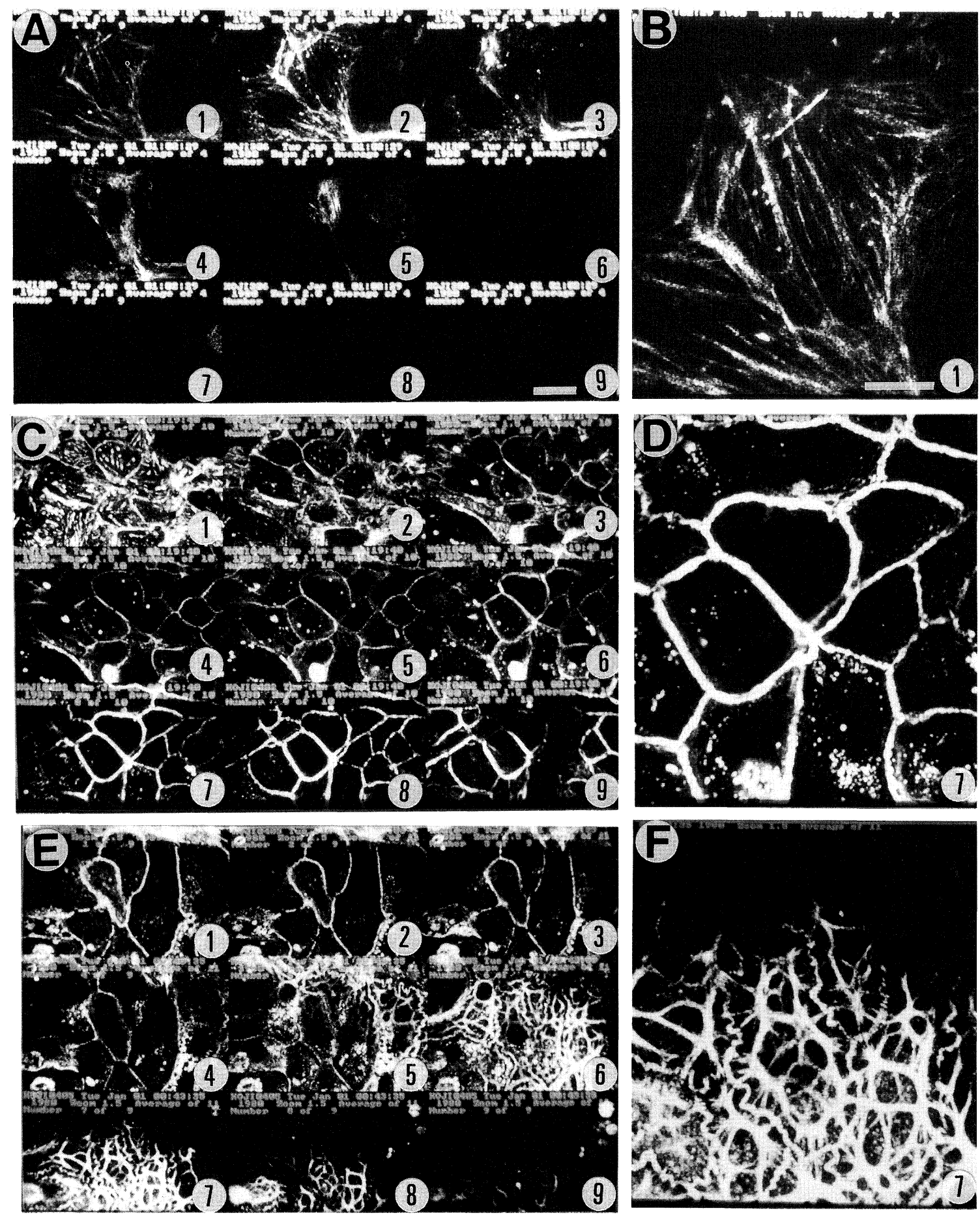

Fig. 2. Confocal laser microscopy in the cultured hepatocytes stained with rhodamine-phalloidin. (A, B) $96 \mathrm{~h}$ after plating. The medium was changed to medium with $2 \%$ DMSO (C, D) or with $2 \%$ DMSO and $10^{-7} \mathrm{M}$ glucagon (E, F) from 96 h. (C, D, E, F) Day 10. (A, C, E) Fluorescence images at every $1 \mu \mathrm{m}$ from the base region of the cells (1) to the apical region (9). (B) is a high magnification of 1 in (A). (D) is a high magnification of 7 in (C). (F) is a high magnification of 7 in (E). Bars: $10 \mu \mathrm{m}$ for A, C and E; $5 \mu \mathrm{m}$ for B, D and F. 

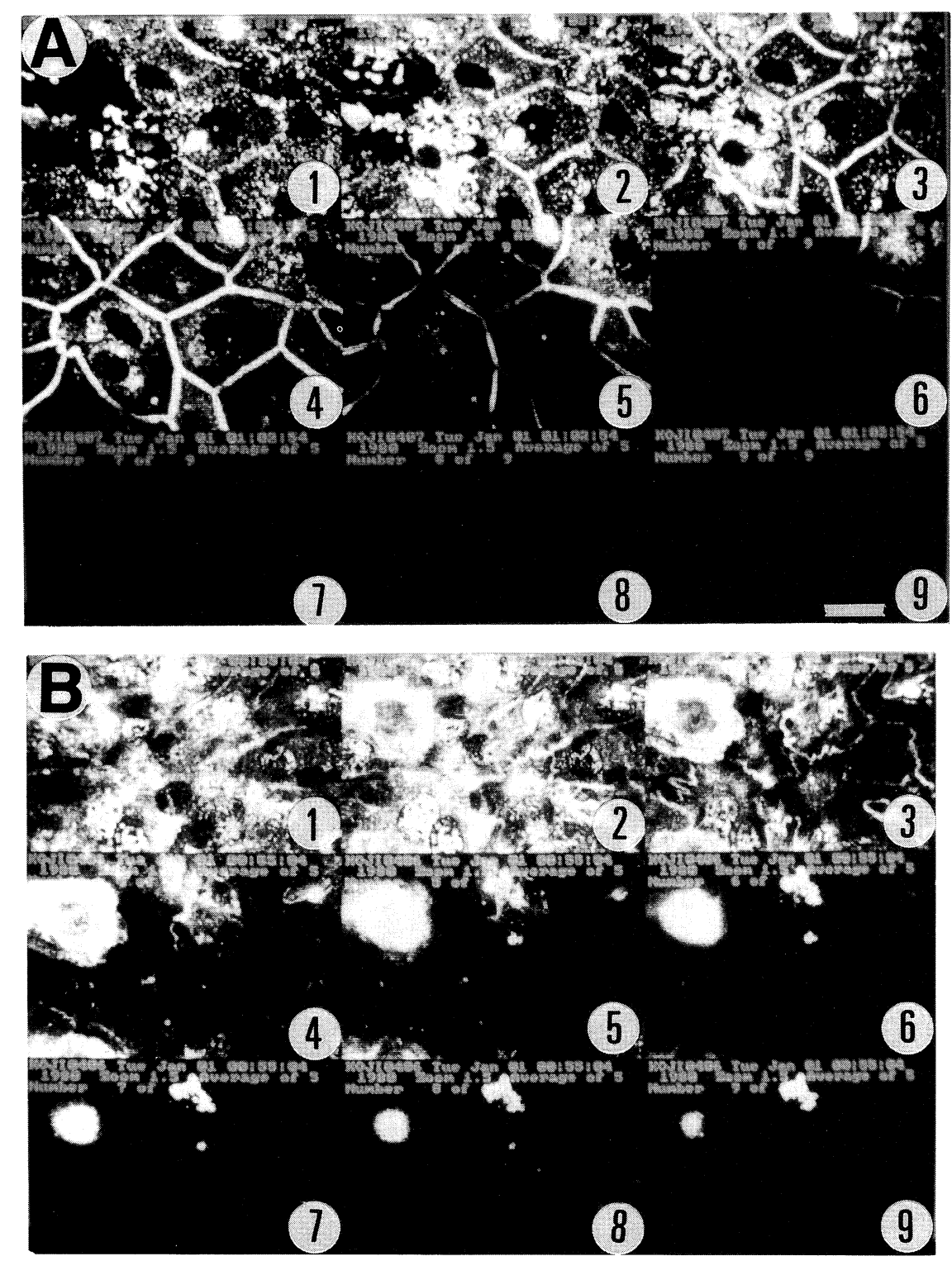

Fig. 3. Confocal laser microscopy in cytochalasin B-treated hepatocytes stained with rhodamine-phalloidin. After the cells were cultured in $2 \%$ DMSO medium with $10^{-7} \mathrm{M}$ glucagon until day 10 , they were treated with 20 (A) or 50 (B) $\mathrm{mg} / \mathrm{ml}$ cytochalasin B for $24 \mathrm{~h}$. (A, B) Fluorescence images at every $1 \mu \mathrm{m}$ from the base region of the cells (1) to the apical region (9). Bars: $10 \mu \mathrm{m}$.

atocytes $(18,19,20)$. We previously showed that in primary cultures of adult rat hepatocytes, a liver gap junction protein, connexin $32(\mathrm{Cx} 32)$ is reexpressed in modified L-15 medium supplemented with EGF and $2 \%$ DMSO (8). In this culture system, after 2\% DMSO was added to the medium, actin filaments were organized into circumferential actin filament bundles under the plasma membrane (Fig. 1E and F). DMSO is a dipolar, aprotic organic solvent which is active in biological systems as a cryoprotectant and a differentiating agent. DMSO are also a powerful scavenger of oxygen radicals on primary cultures of adult rat hepatocytes $(21,22)$. It is thought that actin organization may be closely related to oxidant stress. Furthermore, DMSO can affect the cytoskeleton directly by changes of intercellular calcium levels (23). Thus we thought that these effects of DMSO might induce actin organization in cultured hepatocytes. However, in the culture conditions which added only $2 \%$ DMSO without $10^{-7} \mathrm{M}$ glucagon, the formation of actin filament networks was never observed.

The networks of actin filaments are so called "geodomes" and are observed in cultured rat embryo cells, human skin fibroblast cells and chick embryonic cells $(24,25)$. Furthermore, we previously reported that net- 

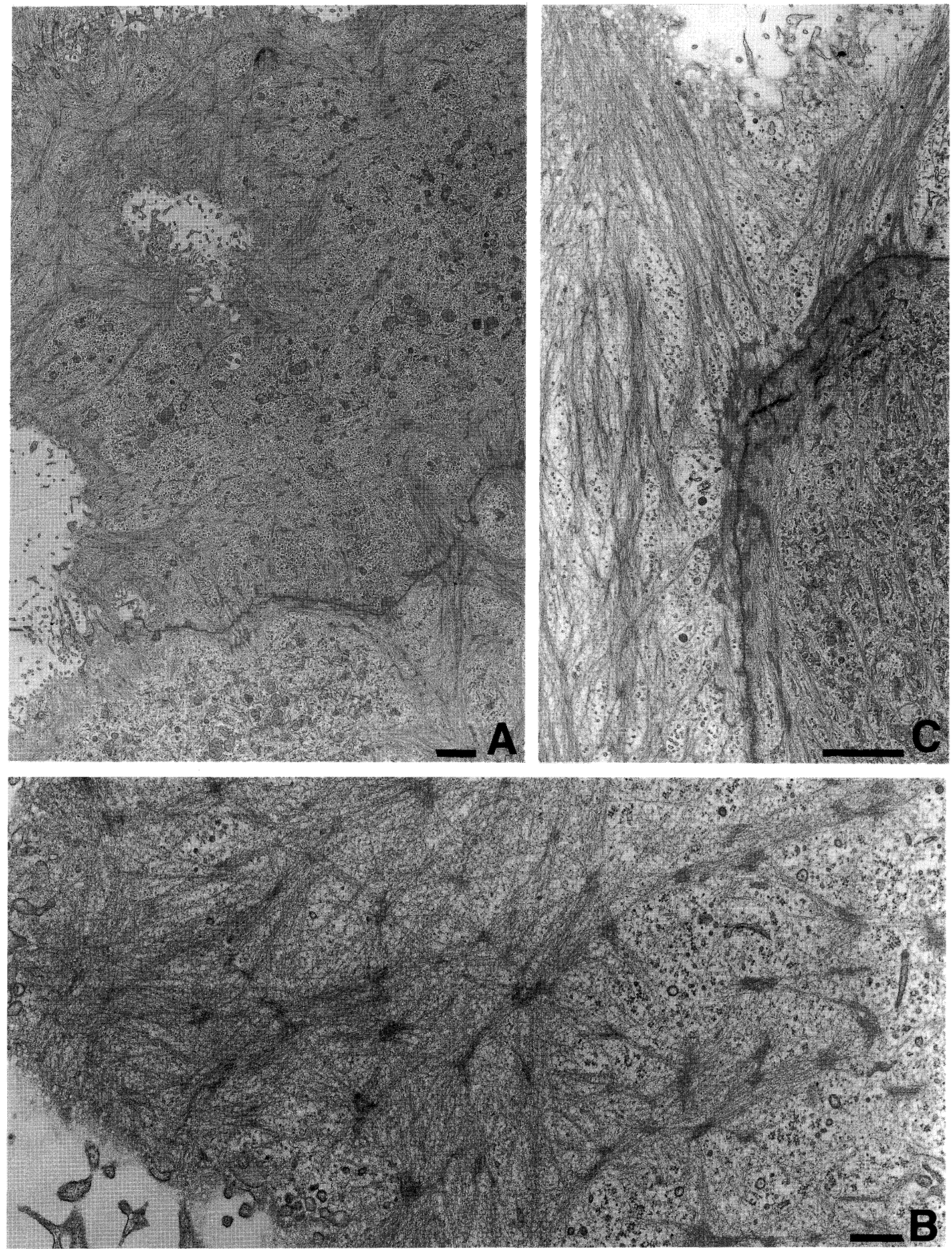

Fig. 4. Electron micrographs of hepatocytes cultured in $2 \%$ DMSO medium with $10^{-7} \mathrm{M}$ glucagon at day 10. (A) Polygonal networks of microfilaments are observed. (B) The networks are composed of electron-dense star-like vertices connected by microfilament bundles of varying length. (C) The microfilaments which formed the networks terminated at the plasma membrane. Bars: $2 \mu \mathrm{m}$ for A and C; $500 \mathrm{~nm}$ for B.

works of actin filaments appeared in cultured hepatocytes from day 5 after plating (26). In the present study, the formation of actin filament networks was observed in hepatocytes cultured in 2\% DMSO medium with $10^{-7} \mathrm{M}$ glucagon from $96 \mathrm{~h}$. The networks of actin filaments developed with time in culture and were well 
A $\frac{\text { hours after plating }}{\text { Control }}$ $\frac{\text { Control }}{038244896}$
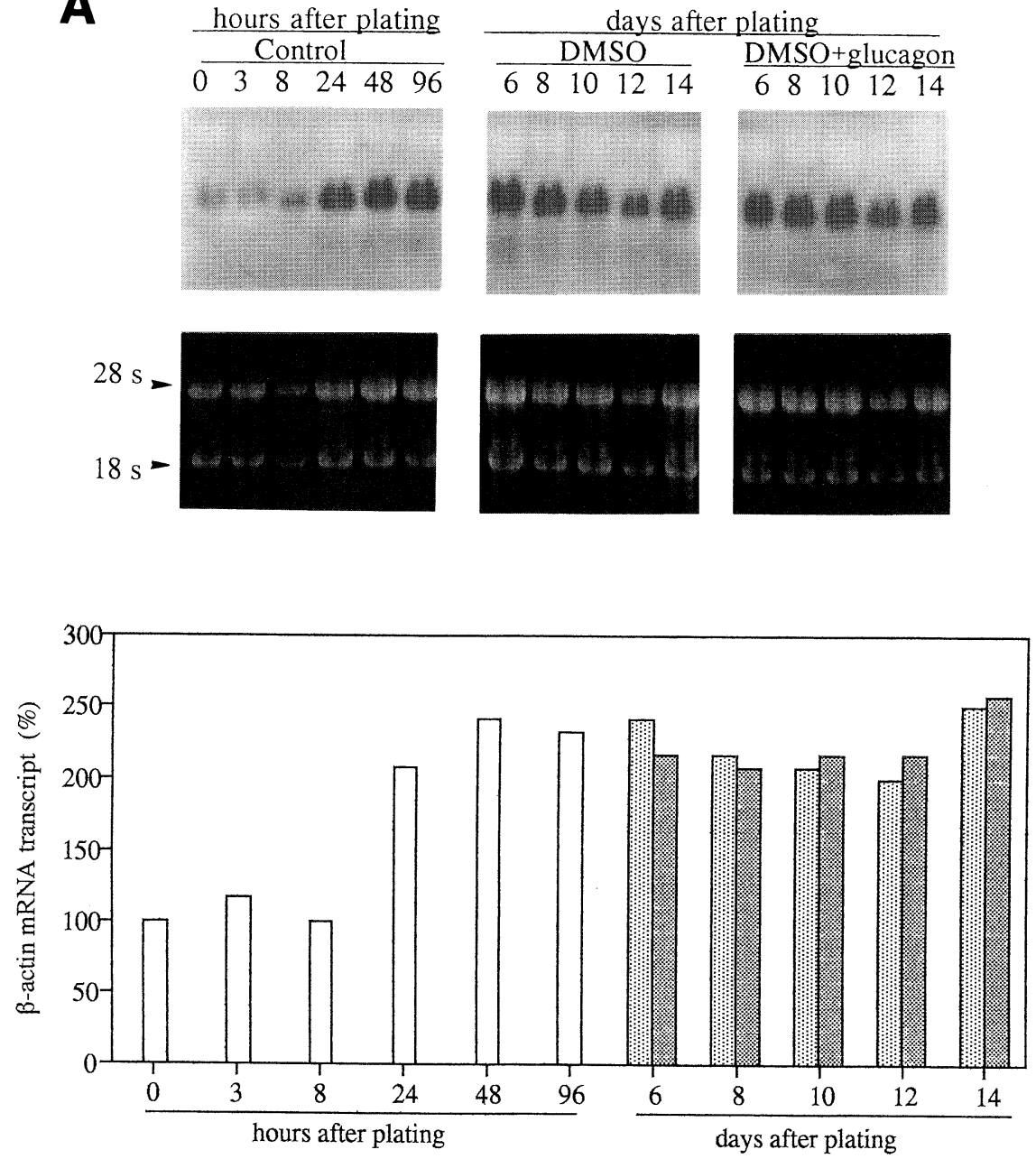

B

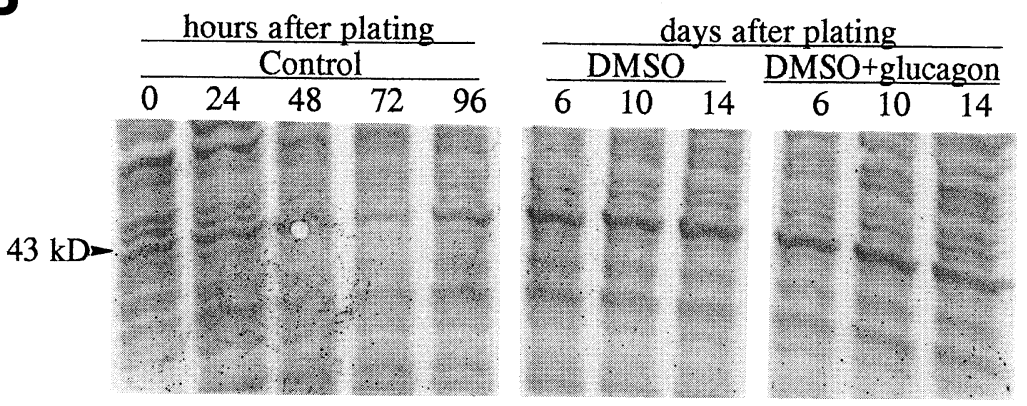

Fig. 5. Northern blot analysis of $\beta$-actin mRNA (A) and Western blot analysis of actin protein (B) in primary cultured rat hepatocytes. (A) For Northern blot analysis, total RNA (10 $\mu \mathrm{g} / \mathrm{lane})$ was fractionated by electrophoresis in a $1 \%$ agarose-formaldehyde gel and hybridized with a digoxigenin-labeled $\beta$-actin cRNA probe (upper panel). The lower panel shows ethidium bromide staining of ribosome RNAs before transfer to membranes. Scanning-densitometric analysis of the mRNA level was performed. Details are described in Materials and Methods. Expression of

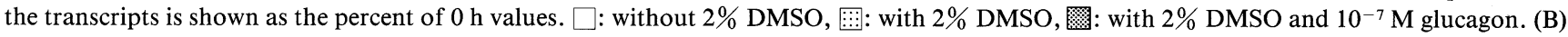
For Western blot analysis, $20 \mu \mathrm{g}$ of protein was separated by electrophoresis in 12.5\% SDS-polyacrylamide gel and transferred to a nitrocellulose membrane. The lanes were reacted with a polyclonal anti-actin antibody. 
maintained. In confocal laser microscopy, the networks of actin filaments were observed as dome-like structures under the apical face. The actin filaments which formed the networks terminated at the circumferential actin filament bundles under the plasma membrane. In electron microscopy, the polygonal networks were composed of electron-dense star-like vertices connected by microfilament bundles of varying length and the microfilaments terminated at the plasma membrane.

The actin disruptor cytochalasin B is a group of fungal metabolites that can cause the dissolution of cortical actin filaments $(2,27)$. In the present study, the networks of actin filaments in the cells were very sensitive to cytochalasin B and disappeared before the circumferential actin filament bundles after the treatment. However, when the cells were cultured without cytochalasin B for $24 \mathrm{~h}$ after treatment with $20 \mathrm{mg} / \mathrm{ml}$ cytochalasin $\mathrm{B}$ for $24 \mathrm{~h}$, the networks recovered completely (data not shown), indicating that the networks were unstable compared to the circumferential actin filament bundles.

On the other hand, during the formation of actin filament networks, there were no significant increases in the amounts of actin protein and mRNA. These results suggested that the formation of actin filament networks was modulated by post-translational mechanisms. Although the precise mechanism of the formation of actin filament networks in hepatocytes remains unknown, it is possible that the polymerization of actin in the cells might be also induced.

Glucagon has an important role in carbohydrate metabolism where, together with insulin, it is a major regulator of plasma glucose concentration. It is also known that glucagon and dibuthyl cyclic AMP have related to the proliferative response of adult rat hepatocytes (28). We have previously shown that in primary cultures of adult rat hepatocytes, a minor liver gap junction protein, $\mathrm{Cx} 26$ was induced by glucagon and dibuthyl cyclic AMP (9). In this experiment, the formation of actin filament networks was observed in the cultured hepatocytes treated with not only glucagon but also dibuthyl cyclic AMP (data not shown). Although there is still no evidence that the formation of actin filament networks in the cultured hepatocytes is induced by glucagon together with DMSO, the effects of glucagon on actin filaments may be associated with the elevated levels of cyclic AMP in the cells.

In this study, the actin network formation, which was observed as a dome-like structure under the apical face of the cells, promoted the maintenance of the height of cells together with the circumferential actin filament bundles. The cell shape and volume may play an important role in the induction and maintenance of differentiated function in hepatocytes (29). In fact, the hepatocytes in this culture system highly maintained differentiated hepatic functions such as albumin, transfer- rin, tryptophan oxygenase, and cytochrome $\mathrm{P}-450$ production $(30,31)$. Furthermore, hepatocytes cultured with DMSO and glucagon also have extensive gap junctional communication between adjacent cells, which is thought to be one of the highly differentiated functions, and they have high expression of Cx32 mRNA and Cx26 mRNA (9). In addition, it is very important in maintenance of differentiated functions that high expression of Cx26 mRNA was observed in the hepatocytes seen in the networks of actin filaments, because Cx26 mRNA may be easily influenced by various factors and unstable in the hepatocytes $(9,32)$. Thus the formation of actin filament networks may play a role in the induction and maintenance of hepatic differentiated functions. Furthermore, one should also consider the possibility that the networks of actin filaments may be used as an intracellular signaling pathway from the plasma membrane to the nuclei. In fact, the cultured hepatocytes which are seen in actin filament networks were more sensitive to the stimulation of hormones and that of DNA synthesis (data not shown).

The present study presents evidence that in cultured hepatocytes using $2 \%$ DMSO medium with $10^{-7} \mathrm{M}$ glucagon, the networks of actin filaments could be induced and maintained for a long-term. Although the real functions of actin filament networks are still unknown, this culture system may be useful for studying the mechanism of the regulation of actin filament networks.

Acknowledgments. We thank Dr. Seizi Ohtani, Ms. Minako Kuwano and Ms. Yohko Takahashi for their technical support. We also thank Mr. Kim Barrymore for help with the manuscript. This work was supported by Grants-in-Aid from the Ministry of Education, Science and Culture, Japan, the Hokkaido Geriatric Research Institute, the Sapporo Medical University Foundation for Research Promotion, the Akiyama Foundation and the Japanese Society of Alternatives to Animal Experiments for Research Promotion.

\section{REFERENCES}

1. Theodoropoulos, P.A., Stournaras, C., Stoll, B., Markogiannakis, E., LANG, F., Gravanis, A., and HAUSSINGER, D. 1992. Hepatocyte swelling leads to rapid decrease of the G-/total actin ratio and increases actin mRNA levels. FEBS Lett., 311: 241-245.

2. Phillips, M.J. Biology and pathology of actin in the liver. 1994. In: The Liver: Biology and Pathology, 3rd ed (eds. I.M. Arias, J.L. Boyer, N. Fausto, W.B. Jakoby, D.A. Schachter and D.A. Shafritz). pp.19-32. Raven Press, New York.

3. Tsukada, N., Ackerley, C.A., and Phillips, M.J. 1995. The structure and organization of the bile canalicular cytoskeleton with special reference to actin and actin-binding proteins. Hepatology, 21: 1106-1113.

4. Ezzell, R.M., Toner, M., Hendricks, K., Dunn, J.C.Y., TompKins, R.G., and YARMUSH, M.L. 1993. Effect of collagen gel configuration on the cytoskeleton in cultured rat hepatocytes. Exp. Cell Res., 208: 442-452.

5. Arterburn, L.M., Zurlo, J., Yager, J.D., Overton, R.M., 
and HeIfeTz, A.H. 1995. A morphological study of differentiated hepatocytes in vitro. Hepatology, 21: 175-187.

6. Ben-Ze'ev, A., Robinson, G.S., BuCher, N.L.R., and FARMER, S.R. 1988. Cell-cell and cell-matrix interactions differentially regulate the expression of hepatic and cytoskeletal genes in primary cultures of rat hepatocytes. Proc. Natl. Acad. Sci. USA, 85: 2161-2165.

7. Musat, A.I., Sattler, C.A., Sattler, G.L., and Pitot, H.C. 1993. Reestablishment of cell polarity of rat hepatocytes in primary culture. Hepatology, 18: 198-205.

8. Kojima, T., Mitaka, T., Paul, D.L., Mori, M., and MochIzUKI, Y. 1995a. Reappearance and long-term maintenance of connexin 32 in proliferated adult rat hepatocytes: use of serum-free L-15 medium supplemented with EGF and DMSO. J. Cell Sci., 108: 1347-1357.

9. Kojima, T., Mitaka, T., Shibata, Y., and Mochizuki, Y. 1995b. Induction and regulation of connexin 26 by glucagon in primary cultures of adult rat hepatocytes. J. Cell Sci., 108: 2771-2780.

10. Seglen, P.O. 1976. Preparation of isolated rat liver cells. Meth. Cell Biol., 13: 29-83.

11. Kreamer, B.L., Staecker, J.L., Sawada, N., Sattler, G.L., Hsia, M.T.S., and Рiтot, H.C. 1986. Use of a low-speed, isodensity Percoll centrifugation method to increase the viability of isolated rat hepatocyte preparations. In Vitro Cell Dev. Biol., 22: 201-211.

12. Michalopoulos, G.K. and Pitot, H.C. 1975. Primary cultures of parenchymal liver cells on collagen membranes: morphological and biological observations. Exp. Cell Res., 94: 7078.

13. Chomczynski, P. and SACCHI, N. 1987. Single-step method of RNA isolation by acid guanidinium thiocyanate-phenol-chloroform extraction. Anal. Biochem., 162: 156-159.

14. XIE, W. and Rothblum, L.I. 1991. Rapid, small-scale RNA isolation from tissue culture cells. Biotechniques, 11: 325-327.

15. Höltke, H.J., Sagner, G., Kessler, C., and Schmitz, G. 1992. Sensitive chemiluminescent detection of digoxigenin-labeled nucleic acids: a fast and simple protocol and its applications. Biotechniques, 12: 104-113.

16. Masters, D.B., Griggs, C.T., and Berde, C.B. 1992. High sensitivity quantification of RNA from gels and autoradiograms with affordable optical scanning. Bio Techniques, 12: 902-911.

17. LAEMMLI, U.K. 1970. Cleavage of structural proteins during the assembly of the head of bacteriophage T4. Nature, 227: 680-685.

18. Isom, H.C., Secott, T., Georgoff, I., Woodworth, C., and Mummaw, J. 1985. Maintenance of differentiated rat hepatocytes in primary culture. Proc. Natl. Acad. Sci. USA, 82: 32523256.

19. Isom, H.C., Georgoff, I., SAlditt-Georgoff, M., and DaRnell, Jr. J.E. 1987. Persistence of liver-specific messenger RNA in cultured hepatocytes: different regulatory events for different genes. J. Cell Biol., 105: 2877-2885.
20. Kost, D.P. and Michalopoulos, G.K. 1991. Effect of $2 \%$ dimethyl sulfoxide on the mitogenic properties of epidermal growth factor and hepatocyte growth factor in primary hepatocyte culture. J. Cell Physiol., 147: 274-280.

21. Wasil, M., Halliwell, B., Grootveld, M., Moorhouse, C.P., Hutchison, D.C.S., and BaUM, H. 1987. The specificity of thiourea, dimethylthiourea and dimethylsulphoxide as scavengers of hydroxyl radicals. Biochem. J., 243: 867-870.

22. Kojima, T., Mitaka, T., Mizuguchi, T., and Mochizuki, Y. 1996. Effects of oxygen radical scavengers on connexins 32 and 26 expression in primary cultures of adult rat hepatocytes. Carcinogenesis, 17: 537-544.

23. Ү амамото, N. 1989. Effect of dimethyl sulfoxide on cytosolic ionized calcium concentration and cytoskeletal organization of hepatocytes in a primary culture. Cell Struct. Funct., 14: 75-85.

24. GoRdon, W.E. and Bushnell, A. 1979. Immunofluorescent and ultrastructural studies of polygonal microfilament networks in respreading non-muscle cells. Exp. Cell Res., 120: 335-348.

25. Ireland, G.W. and Voon, F.C.T. 1981. Polygonal networks in living chick embryonic cells. J. Cell Sci., 52: 55-69.

26. Mochizuki, Y., Furukawa, K., Mitaka, T., Yokoi, T., and Kodama, T. 1988. Polygonal networks, "geodomes", of adult rat hepatocytes in primary culture. Cell Biol. Int. Rep., 12: 1-7.

27. MacLean-Fletcher, S. and Pollard, T.D. 1980. Mechanism of action of cytochlasin B on actin. Cell, 20: 329-341.

28. McGowan, J.A., Strain, A.J., and Bucher, N.L.R. 1981. DNA synthesis in primary cultures of adult rat hepatocytes in a defined medium: effects of epidermal growth factor, insulin, glucagon, and cyclic-AMP. J. Cell Physiol., 108: 353-363.

29. HÄUSSINGER, D. and LANG, F. 1991. Cell volume in the regulation of hepatic function: a mechanism for metabolic control. Biochim. Biophys. Acta., 1071: 331-350.

30. MitaKa, T., NoRioKa, K., and MochizUKI, Y. 1993. Redifferentiation of proliferated rat hepatocytes cultured in L15 medium supplemented with EGF and DMSO. In Vitro Cell Dev. Biol., 29A: 714-722.

31. Mizuguchi, T., Mitaka, T., Kojima, T., Hirata, K., NaKamura, T., and MochizUKI, Y. 1996. Recovery of mRNA expression of tryptophan 2,3-dioxygenase and serine dehydratase in long-term cultures of primary rat hepatocytes. $J$. Biochem., 120: 511-517.

32. Stutenkemper, R., Geisse, S., Schwarz, H.J., Look, J., Traub, O., Nicholson, B., and Willecke, K. 1992. The hepatocyte-specific phenotype of murine liver cells correlates with high expression of connexin 32 and connexin 26 but very low expression of connexin 43. Exp. Cell Res., 201: 43-54.

(Received for publication, November 11, 1996 and in revised form, January 20, 1997) 